UDC 634.7:631,52:691.217

http://journals.nubip.edu.ua/index.php/Biologiya/editor/submission/13081

\title{
INFLUENCE OF ANALCIME ON THE GROWTH OF SEEDLINGS OF NON-TRADITIONAL BERRY CROPS
}

\author{
N.V. SKRYPCHENKO, PhD in Biology, senior researcher, \\ V.F. LEVON, PhD in Chemistry, senior researcher, \\ G.V. SLYUSAR, lead engineer \\ Department of Fruit Plants Acclimatization \\ M. Grishko National Botanical Garden of National Academy of Sciences of Ukraine \\ E-mail: actinadiia@gmail.com
}

\begin{abstract}
Analcime is a natural mineral of volcanic origin, which in accordance with previous studies has a positive effect on the functional state of living organisms, stimulates the growth and development of plants, increases their productivity and resistance to biotic and abiotic factors. The influence of the analcime on morphological, biometric and biochemical parameters of seedlings of Schizandra chinensis (Turcz.) Baill., Actinidia arguta Planch., Lonicera caerulea L., Elaeagnus multiflora Thunb. and Viburnum opulus L. when it is adding to the soil. It is shown that the exogenous use of the mineral contributes to the growth and development of the root and aboveground system of plants, increases their resistance to adverse abiotic environmental factors. A significant increase of shoots have V. opulus and E. multiflora (38\% and $76.8 \%$ respectively) compared to the control plants. At the same time, the greatest increase in roots was observed among L. caerulea plants (47.1\%). The greatest effect of analcime on growth of roots was noted in the variant with $V$. opulus, the weight of which was more than $77.6 \%$ compared with the control. The addition of mineral into the soil contribute to the increase in the flavonoid content in the leaves of experimental plants and reduce the proline content. The study of the content of flavonoids in the leaves of experimental plants, as one of the indicators of nonspecific stress response to drought, has showed that the addition of $50 \mathrm{~g} / \mathrm{m} 2$ of analcime to soil lead to the increasing of the total content of flavonoids by 33-45\% in the leaves of all studied objects. The increasing of the dose of analcime in the soil to $100 \mathrm{~g} / \mathrm{m} 2$ area almost did not cause a further increasing of the amount of flavonoids in the leaves of the studied objects, but on the contrary, there was a slight recession of this indicator by 2-9\%.

While soil application of $100 \mathrm{~g}$ for the analcime square meter, the content of proline decreases $1 \mathrm{mmol} / \mathrm{g}$, which indicates a positive anti-stress action of analcime on the seedlings $V$. opulus. At the same time, species specificity and dose dependence of the mineral action on experimental plants were noted.

The analysis of the results indicates the perspectivity of using analcime to increase the resistance of berry plants to negative environmental factors and stimulate their growth and development for the cultivation of planting material.
\end{abstract}

Keywords: zeolite, analcime, non-traditional berry plants, S. chinensis, A. arguta, L. caerulea, E. multiflora, V. opulus, stress tolerance, flavonoids, proline 


\section{Introduction.}

In connection with global climate changes, the urgency of the issue of increasing stress resistance of plants, in particular the drought-tolerance of plants, has become the matter of current interest now. Drought, which has been observed more and more recently, is increasingly endangering the harvest of many agricultural and garden crops, impedes their successful reproduction and introduction to agrocenosis. The important problems of gardening include improving of the technology of obtaining high-quality berry plant seedlings by vegetative propagation and the use of biologically active drugs that would increase the adaptive properties of plants and, as a result, the output of standard high quality seedlings.

One of the ways to solve this problem is the use of natural minerals, in particular, zeolites. It is known that silicon is involved in counteracting plant stress caused by excessive amounts of magnesium, aluminum and heavy metals, salinity, water deficit, frost and reduced positive temperatures. A number of mechanisms of counteracting to stress in plants, which, probably, are stimulated with silicon, have been identified: 1) promoting the work of antioxidant systems; 2) formation of complex with ions of toxic metals, as well as co-precipitation due to silicon compounds; 3 ) immobilization of ions of toxic metals in the external environment of growth; 4) influence on the processes of absorption (and assimilation); 5) compartmentation of metal ions in a plant organism (Liang et al., 2007). Many studies have reported that Si mitigates the effects of abiotic stresses such as salinization and drought (Guntzer, 2012, Zhu \& Gong, 2014).

Zeolite are ecologically safe natural meliorants, the use of which contributes to resource conservation, improvement of soil properties and aeration, increase productivity and systemic stability of cultivated plants. The positive effect of zeolites on the growth and development of plants is associated with increasing of plant resistance to stress factors, more intense absorption of water along with nutrients (Zaimenko, 2016).

Zeolites are especially widespread in areas of young volcanism: in the United States in new Jersey; in India, Russia, Armenia, Bulgaria, Hungary, Iceland, Cuba, Mongolia, New Zealand, Japan and Ukraine (Crimea and the Carpathians).

Analcime $\mathrm{Na}\left[\mathrm{AlSi}_{2} \mathrm{O}_{6}\right] \cdot \mathrm{H}_{2} \mathrm{O}$ is a mixture of minerals (mostly zeolite group), in which the clay component represented by montmorillonite. The analcime contains more than 30 biogenic elements in the form available for plants, including silicon (13-15\%). This natural mineral of volcanic origin, which according to many studies has a positive effect on the functional state of living organisms, stimulates the development of root and aboveground mass of plants, improving the mechanical properties of plant tissues, increasing their productivity, ensuring plant resistance to biotic and abiotic factors (Martynenko, 2014, Zaimenko 2016, 2017).

Intruders of the Far East flora - species of the genus Actinidia L., S. chinensis, L. caerulea - are the plants of moist climate. Therefore, creating the optimal conditions for their growth and development in relation to the requirements for external factors is a very important issue. Plant resistance to soil and air drought during the summer period (drought tolerance) is important under the plant introduction in the Forest-steppe of Ukraine. Under conditions of water supply, Kyiv-city refers to a zone of inadequate moistening - during the year there are 
500-590 $\mathrm{mm}$ precipitation, distributed unevenly, the average relative humidity is $76 \%$. Arid conditions adversely affect on the growth and development of those plants, complicate the process of growing of planting material.

The purpose of the study - to research the effect of a natural silicon containing mineral analcime on the growth and development of seedlings of fruit crops for growing of planting material under Right Bank Forest-steppe of Ukraine conditions.

\section{Materials and methods.}

Experimental work was carried out in M. Gryshko National Botanical Garden of NAS of Ukraine. The object of the study was analcime - natural silicon-containing mineral; one year old seedlings of $\mathrm{S}$. chinensis, A. arguta, L. caerulea, E. multiflora та V. opulus served as test-plants.

Natural mineral analcim was added into the soil before planting in concentrations of 50 and $100 \mathrm{~g} / \mathrm{m}^{2}$. Biometric parameters of plants, namely the intensity of growth of roots and shoots of plants, as well as their weight were investigated.

The content of flavonoids was determined by a technique based on their ability to form a colowred complex with an alcohol solution of aluminum chloride, which causes a long-wavelength absorption band shift and gives the main absorption maximum at a wavelength of $400 \mathrm{~nm}$. A similar maximum absorption at a wavelength of $400 \mathrm{~nm}$ was observed for the complex of the state standard sample luteolin-7-glycoside (cinaroside), used by us in the technique as a standard sample (Андреева, 2000). The stress state of the plants was also analyzed according to the content of proline, which was determined by the method (Bates et al., 1993). Plant material $(0.5 \mathrm{~g})$ was homogenized in 10 $\mathrm{ml}$ of 3\% aqueous solution of sulfosalicylic acid, homogenate was filtered. After that, $2 \mathrm{ml}$ of filtrate was added to the mixture of ninhydrin and glacial acetic acid and kept in a test tube for 1 hour at $100^{\circ} \mathrm{C}$. The reaction mixture was extracted with toluene. The stained solution was investigated by spectrophometric method at a wavelength of $520 \mathrm{~nm}$, using toluene as a control. The proline concentration was determined by the standard curve and calculated in terms of the mass of the raw material.

Statistical processing of the research results was performed by methods of descriptive statistics and univariate analysis of variance using Statistica 10.0 and Microsoft Office Excel.

\section{Results and discussion.}

The results of studies have shown that the use of silicon-containing mineral stimulated the growth of one year old shoots and roots of experimental plants. A significant increase of shoots has V. opulus and E. multiflora $(38.0 \%$ and $76.8 \%$ respectively compared to the control) plants. At the same time, the greatest increase in roots was observed among $L$. caerulea plants $(47.1 \%)$ (Fig. 1, 2).

The greatest effect of analcime on growth of roots was noted in the variant with $V$. opulus, the weight of which was more than $77.6 \%$ compared with the control (Fig. 3).

At the same time, it was noted species-specific and dose-dependent effect of the mineral. So, the highest increase of shoots, length and weight of root system of the L. caerulea plants were recorded in the variant with the addition of $100 \mathrm{~g} /$ $\mathrm{m}^{2}$ of the analcime. However, the dose of $50 \mathrm{~g} / \mathrm{m}^{2}$ turned out to be more effective 


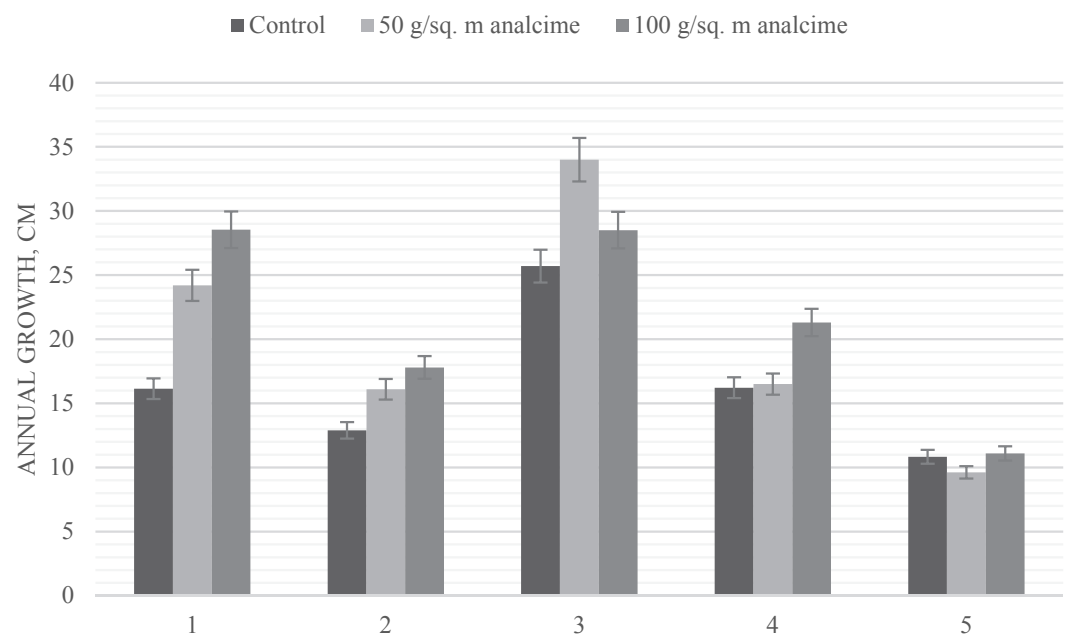

Fig. 1. The influence of the analcime on growth of shoots of berry crops: $1-$ V. opulus; $2-$ L. caerulea; $3-$ E. multiflora; $4-$ A. arguta; $5-S$. Chinensis

for E. multiflora. The addition of $50 \mathrm{~g} /$ $\mathrm{m}^{2}$ of analcime to A. arguta have led to a slight increase of the root mass, while a significant increase in the growth of shoots was noted in the variant with the addition of $100 \mathrm{~g} / \mathrm{m}^{2}$ of the mineral. The stimulating action of the analcime in the growth and development of seedlings of
S. chinensis was noted in both versions of the investigation.

The positive impact of the analcime was established at cultivation of planting material of $V$. opulus ordinary, especially in drought conditions. There was a significant increase in all biometric parameters of plants and especially the

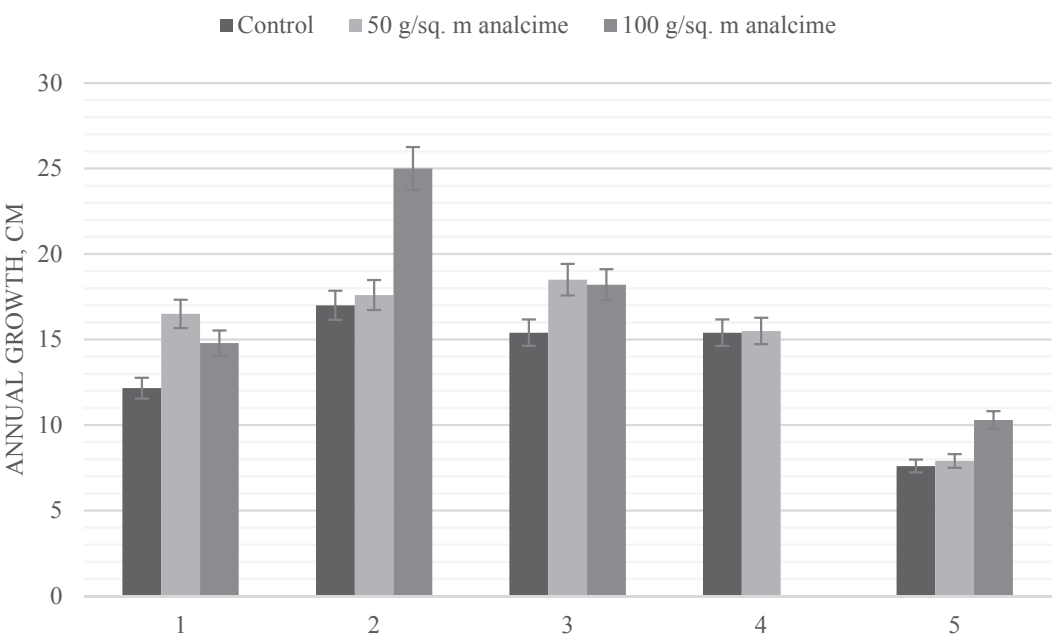

Fig. 2. The influence of the analcime in the length of roots:

$1-V$. opulus; $2-L$. caerulea; $3-E$. multiflora; $4-A$. arguta; $5-S$. chinensis 


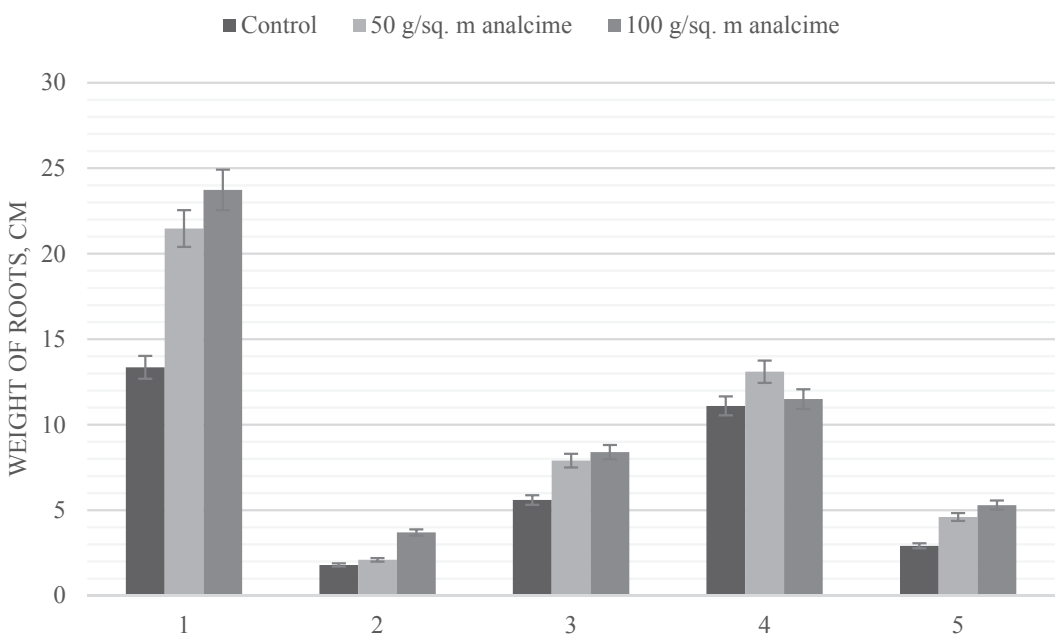

Fig. 3. Weight of roots of berry crops under the adding of analcim:

$1-V$. opulus; $2-L$. caerulea; $3-E$. multiflora; $4-A$. arguta; $5-S$. chinensis

mass of roots when applied to the soil $50 \mathrm{~g} / \mathrm{m}^{2}$ analcime. The concentration of $100 \mathrm{~g} / \mathrm{m}^{2}$ for this species was the most effective-the mass of roots increased almost 2 times compared to the control, and the length of sprouts - by $45 \%$.

Significant increase of all biometric parameters was observed for $V$. opulus plants, when $50 \mathrm{~g} / \mathrm{m}^{2}$ of analcium was added to soil. The analcium concentration of $100 \mathrm{~g} / \mathrm{m}^{2}$ for this species proved to be most effective: the mass of the roots increased almost twice compared to control, and the length of the shoots - by $45 \%$.

Thus, the use of the analcime in the cultivation of planting material of investigated berry plants may be considered as an important factor in increasing the efficiency of the process.

The study of the content of flavonoids in the leaves of experimental plants, as one of the indicators of non-specific stress response to drought, has showed that the addition of $50 \mathrm{~g} / \mathrm{m}^{2}$ of analcime to soil lead to the increasing of the total content of flavonoids by $33-45 \%$ in the leaves of all studied objects (Fig. 4). It may be assumed that this is due to the processes of chemisorption of flavonoids, which are contained in the rhizosphere layer of the soil on the surface of the analcime. Insufficient amount of flavonoids in the root layer of the soil leads to increased biosynthesis in the plant organism.

It should be noted that increasing of the dose of analcime in the soil to 100 $\mathrm{g} / \mathrm{m}^{2}$ area almost did not cause a further increasing of the amount of flavonoids in the leaves of the studied objects, but on the contrary, there was a slight recession of this indicator to $9 \%$.

The indicators of non-specific stress reaction on the drought include the synthesis of proteins, in particular, proline. Studies of the leaves of $V$. opulus on the content of proline (Fig. 5) showed that adding of the analcime to the soil in an amount of $50 \mathrm{~g} / \mathrm{m}^{2}$, a decrease of its content in comparison with control.

Under adding of $100 \mathrm{~g}$ analcime for the square meter, the content of proline decreases $1 \mathrm{mmol} / \mathrm{g}$, which indicates a positive anti-stress action of analcime on the seedlings of $V$. opulus. 


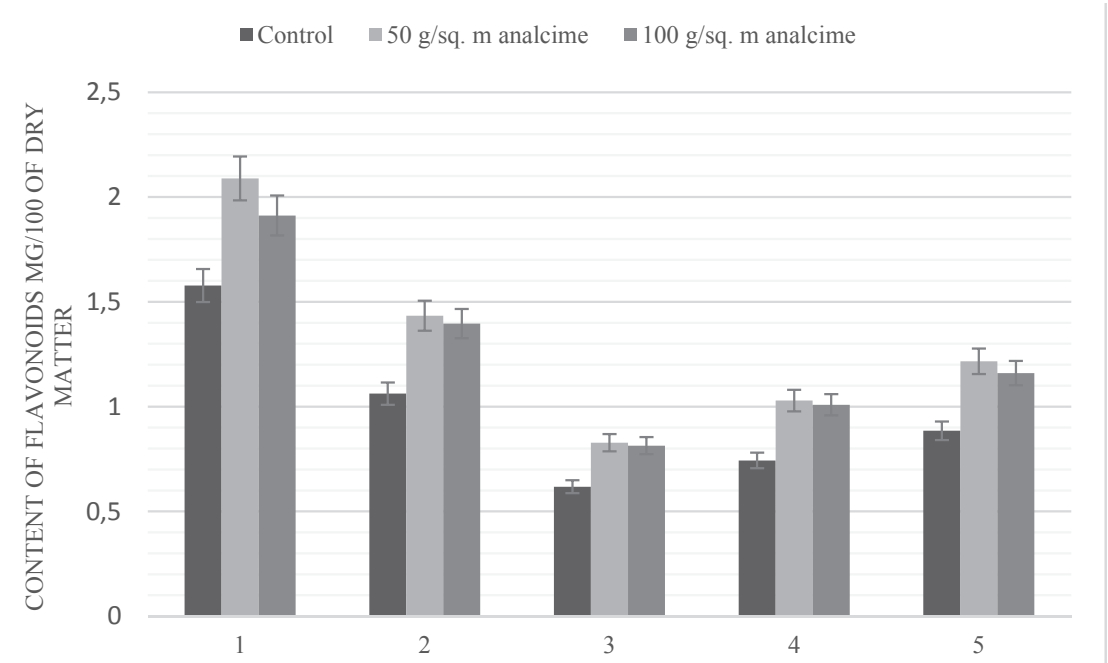

Fig. 4. The content of flavonoids in the leaves of berry crops under the adding of analcime: $1-V$. opulus; $2-L$. caerulea; $3-$ E. multiflora; $4-A$. arguta; $5-S$. chinensis

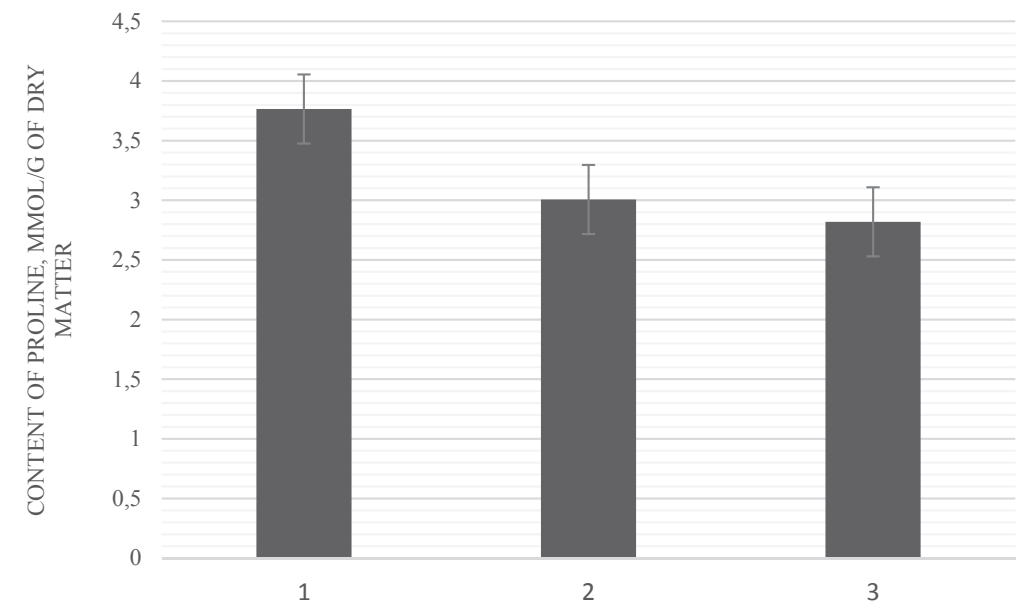

Fig. 5. The content of proline in the leaves of $\mathrm{V}$. opulus under the adding of analcime: 1 - control; $2-50 \mathrm{~g} / \mathrm{m}^{2}$ analcime; $3-100 \mathrm{~g} / \mathrm{m}^{2}$ analcime

\section{Conclusions.}

As a result of the research, it was found that the using of analcime in the cultivation of berry seedlings is a powerful stimulant of the ontogenesis of plants, which increases their adaptive and protective potential, demonstrating resistance to stress over a long period. Analcim contributes to the growth of plants, significantly increasing the mass of roots and above ground organs. In order to improve the agrotechnics of growing berry planting material and in- 
creasing of this process efficiency, the optimum concentration of the use of natural mineral is $50 \mathrm{~g} / \mathrm{m}^{2}$.

The adding to the soil of analcime helps to increase the stress resistance of plants, which is accompanied with a decreasing of the proline and an increasing of the flavonoids content of in the vegetative organs of plants.

\section{References.}

1. Andreeva, V. YU., Kalinkina, G. I. (2000). Razrabotka metodiki kolichestvennogo opredeleniya flavonoidov $v$ manzhetke obyknovennoj Alchemilla vulgaris L.S.L. [Development of methods for the quantitative determination of flavonoids in the cuff ordinary Alchemilla vulgaris L.S.L.]. Chemistry of plant materials, 1, 85-88.

2. Zaimenko, N. V., Ellanska, N. E., Didyk, N. P., Pavliuchenko, N. A., Yunosheva, O. P., Ivanytska, B. O., Zakrasov, O. V., Rositska, N. V. (2016). Vplyv analtsymu ta ekzometabolitiv hryba Penicillium roseopurpureum na stiikist tomativ do fuzariozu, mikrobiolohichni ta alelopatychni vlastyvosti gruntu [Effect of analcime and exometabolites of fungus Penicillium roseopurpureum on the stability of tomatoes to fusariosis, microbiological and allelopathic properties of soil]. Dopovidi Natsionalnoi akademii nauk Ukrainy, 11, 93-98. doi: https://doi. org/10.15407/dopovidi2016.11.093

3. Zaimenko, N. V., Pavliuchenko, N. A., Ellanska, N. E., Yunosheva, O. P., Ivanytska, B. O., Kharytonova, I. P, Didyk, N. P., Rositska, N. V. (2017).
Perspektyvy zastosuvannia kremniievmisnoi orhano-mineralnoi sumishi dlia znyzhennia gruntovtomy $v$ plodovykh sadakh [Prospects for the use of silicon-containing organo-mineral mixture for the reduction of soil fatigue in fruit gardens]. Dopovidi Natsionalnoi akademii nauk Ukrainy, 11, 76-82.

4. Martynenko, O. I., Kirilenko, T. K., Zaimenko, N. V., Antonyuk, M. N., Stepanyugin, A. V., Plodnik, D. P., Govorun, D. N. (2014). Vzaimosvyaz' mezhdu sootnosheniem RNK/DNK, skorost'yu rosta i akkumulyaciej selena v kletkah list'ev pshenicy pod vozdejstviem mineralov anal'cima i trepela [The relationship between the ratio of RNA / DNA, growth rate and accumulation of selenium in the cells of wheat leaves under the influence of the minerals analcime and trepel]. Ukr. Biochem. J., 86(5), 89-94. doi: https://doi.org/10.15407/ubj86.05.089

5. Bates, L. S., Valdren, R. R., Theare, G. D. (1993). Rapid determination of free proline for water-stress studies. Plant and soil, 1, 205-207.

6. Guntzer, F., Keller, C., Meunier, J. (2012). Benefits of plant silicon for crops: a review. Agron. Sustain. Dev., 15, 8933-8952. doi: https: // doi.org/10.3390/molecules 15128933

7. Liang, Y., Sun, W., Zhu, Y. G., Christie, P. (2007). Mechanisms of silicon-mediated alleviation of abiotic stresses in higher plants: a review. Environmental Pollution, 147(2), 422-428.

8. Zhu, Y. Gong, H. (2014). Beneficial effects of silicon on salt and drought tolerance in plants. Agronomy for Sustainable Development, 34(2), 455-472. doi: 10.1007/ s13593-013-0194-1.

\section{Н. В. Скрипченко, В. Ф. Левон, Г. В. Слюсар (2019). ВПЛИВ АНАЛЬЦИМУ НА РІСТ І РОЗВИТОК СІЯНЦІВ НЕТРАДИЦІЙНИХ ЯГІДНИХ КУЛЬТУР. BIOLOGICAL SYSTEMS: THEORY AND INNOVATION, 10(3): 63-70. http://journals.nubip.edu.ua/index.php/Biologiya/editor/submission/13081}

Анотація. Анальцим - це природний мінерал вулканічного походження, який відповідно до попередніх досліджень позитивно впливає на функціональний стан живих 
організмів, стимулює ріст та розвиток рослин, підвищує їх продуктивність та резистентність до дії біотичних та абіотичних факторів. Досліджено вплив анальциму на морфолоічні та біохімічні показники саджанців Schizandra chinensis (Turcz.) Baill., Actinidia arguta Planch., Lonicera caerulea L., Elaeagnus multiflora Thunb. ma Viburnum opulus L. за внесення його в грунт. Показано, що екзогенне застосування мінералу сприяє росту та розвитку кореневої і надземної системи рослин, підвищує їх стійкість до несприятливих абіотичних факторів середовища. Значний приріст пагонів мали V. opulus i E. tultiflora (відповідно 38 \% і 76,8 \%) порівняно з контрольними рослинами. У той же час найбільший приріст коренів спостерігалося у рослин L. caerulea (47,1 \%). Найбільший вплив анальциму на ріст коренів відзначений у варіанті з V. ориlus, вага яких збільшилась на 77,6\% у порівнянні з контролем. Додавання мінералу до грунту сприяє збільшенню вмісту флавоноїдів у листках дослідних рослин та зменшенню вмісту проліну. Дослідження вмісту фллвоноїдів у листках дослідних рослин, як одного з показників неспецифрічної реакції стресу на посуху, показало, що додавання 50 г/м2 анальциму до грунту призводить до збільшення загального вмісту флавоноїдів на 33-45 \% у листках усіх досліджуваних об'єктів. Збільшення дози анальцима в грунті до 100 г/м2 практично не призвело до подальшого збільшення кількості фрлавоноїдів у листках досліджуваних облєктів, а навпаки, спостерігався невеликий спад цього показника на 2-9\%. За внесенні в ґрунт 100 г анальциму на один квадратний метр уміст проліну зменшується на 1 ммоль/г, що свідчить про позитивну антистресову дію анальціму на саджанці V. ориlus. У той же час, відзначена видова специфічність і дозозалежність дії мінералу на дослідних рослинах.

Аналіз отриманих результатів свідчить про перспективність використання анальциму для підвищення стійкості ягідних рослин до негативних факторів навколишнього середовища, стимулювання їх росту та розвитку для вирощування посадкового матеріалу.

Ключові слова: чеоліт, анальцим, нетрадиційні ягідні рослини, S. chinensis, A. arguta, L. caerulea, E. multiflora, V. opulus., cтресостійкість, фллавоноїди, пролін 